\title{
Functional genomics studies of oocyte competence: evidence that reduced transcript abundance for follistatin is associated with poor developmental competence of bovine oocytes
}

\author{
Osman V Patel ${ }^{1,4}$, Anilkumar Bettegowda ${ }^{1,4}$, James J Ireland ${ }^{2,3,4}$, Paul M Coussens ${ }^{3,4}$, \\ Patrick Lonergan ${ }^{6}$ and George W Smith ${ }^{1,3,4,5}$ \\ ${ }^{1}$ Laboratory of Mammalian Reproductive Biology and Genomics, ${ }^{2}$ Molecular Reproductive Endocrinology \\ Laboratory, ${ }^{3}$ Center for Animal Functional Genomics, Departments of ${ }^{4}$ Animal Science and ${ }^{5}$ Physiology, Michigan \\ State University, East Lansing, Michigan 48824, USA and ${ }^{6}$ Department of Animal Science and Centre for Integrative \\ Biology, University College Dublin, Dublin, Ireland
}

Correspondence should be addressed to G W Smith; Email: smithge7@msu.edu

\begin{abstract}
Poor oocyte competence contributes to infertility in humans and livestock species. The molecular characteristics of such oocytes are generally unknown. Objectives of the present studies were to identify differences in RNA transcript abundance in oocytes and early embryos associated with reduced oocyte competence and development to the blastocyst stage. Microarray experiments were conducted using RNA isolated from germinal vesicle stage oocytes collected from adult versus prepubertal animals (model of poor oocyte competence). A total of 193 genes displaying greater mRNA abundance in adult oocytes and 223 genes displaying greater mRNA abundance in prepubertal oocytes were detected. Subsequent gene ontology analysis of microarray data revealed significant overrepresentation of transcripts encoding for genes in hormone secretion classification within adult oocytes and such genes were selected for further analysis. Real-time PCR experiments revealed greater abundance of mRNA for $\beta A$ and $\beta B$ subunits of inhibin/activin and follistatin, but not the $\alpha$ subunit in germinal vesicle stage oocytes collected from adult versus prepubertal animals. Cumulus cell follistatin and $\beta B$ subunit $m R N A$ abundance were similar in samples collected from prepubertal versus adult animals. A positive association between time of first cleavage (oocyte competence) and follistatin mRNA abundance was noted. Follistatin, $\beta B$, and $\alpha$ subunit mRNAs were temporally regulated during early bovine embryogenesis and peaked at the 16-cell stage. Collectively, results demonstrate a positive association of follistatin mRNA abundance with oocyte competence in two distinct models and dynamic regulation of follistatin, $\beta B$, and $\alpha$ subunit mRNAs in early embryos after initiation of transcription from the embryonic genome.

Reproduction (2007) 133 95-106
\end{abstract}

\section{Introduction}

Oocyte competence, defined as the ability of an oocyte to be fertilized and develop to the blastocyst stage is progressively acquired during the period of oocyte growth accompanying follicular development (Eppig et al. 2002, Matzuk et al. 2002). Pituitary gonadotropins and bidirectional local communication between the oocyte and adjacent somatic (cumulus) cells are critical for both nuclear and cytoplasmic maturation (acquisition of ability to complete meiosis, ensure monospermic fertilization, and undergo preimplantation development; Eppig 1991, Eppig et al. 2002, Gosden 2002, Matzuk et al. 2002). Competencies acquired by the nuclear and the cytoplasmic compartments during final stages of maturation support the notion that oocyte quality depends on a multiplicity of factors, many of which can be assessed only at the molecular level. However, the molecular characteristics (at the level of mRNA transcript profiles) of competent oocytes are not known.

To date, morphological parameters, such as shape, homogeneity of cytoplasm, presence of polar body, and compactness of cumulus cells have routinely been utilized as markers of oocyte competence, and in the final analysis select for and generate embryos of increased developmental potential (Armstrong 2001, Lonergan et al. 2001, 2003a, Coticchio et al. 2004, Krisher 2004). However, it is well known that morphological criteria alone are insufficient to distinguish competent oocytes that have the ability to bring about 
a full-term pregnancy (Lonergan et al. 2003a, Coticchio et al. 2004, Krisher 2004). For these reasons, investigation of the molecular characteristics of oocytes of poor developmental competence is critical to form a foundation for the development of future classification criteria for the selection of oocytes with superior developmental capacity.

Two well-defined bovine models for investigation of oocyte developmental competence are the prepubertal calf model and the time of first cleavage. Antral follicles with fully grown oocytes are present in calves at or prior to birth, but overall success of pregnancies from in vivo and in vitro produced embryos derived from oocytes of prepubertal animals is low (Seidel et al. 1971, Revel et al. 1995, Gandolfi et al. 1998, Khatir et al. 1998a, 1998b, Armstrong 2001, Palma et al. 2001). Oocytes collected from prepubertal animals display reduced activity of maturation promoting factors, mitogenactivated protein kinase and cyclin B, altered protein synthesis, aberrant energy metabolism, less $\mathrm{Ca}^{2+}$ influx at fertilization, and an overall reduced embryo survival post-fertilization (Levesque \& Sirard 1994, Revel et al. 1995, Gandolfi et al. 1998, Khatir et al. 1998a, 1998b, Steeves \& Gardner 1999, Armstrong 2001, Palma et al. 2001, Salamone et al. 2001). Despite evidence of biochemical defects in prepubertal oocytes, comparatively less is known about the molecular characteristics of such oocytes, manifested at the level of differences in mRNA transcript profiles between oocytes collected from prepubertal versus adult animals.

The relationship between the kinetics of early embryonic cleavage and subsequent development has been well established in cattle and humans (McKiernan \& Bavister 1994, Plante et al. 1994, Sakkas et al. 1998, Shoukir et al. 1998, Brevini et al. 2002, Rizos et al. 2002, Lonergan et al. 2003b, Gutierrez-Adan et al. 2004). Such relationships suggest that whether or not an embryo will reach the blastocyst stage is determined in part by events that occur prior to the two-cell stage. While limited transcription does occur at or before the two-cell stage (Memili \& First 1999), the two-cell stage embryo is absolutely dependent on transcripts and proteins sequestered from the oocyte for its progressive development until the maternal-zygotic transition when the maternal RNA pool is replaced via significant transcription from the embryonic genome. The maternal-zygotic transition occurs at the 8-16 cell stage in cattle (Telford et al. 1990, Memili \& First 1998, 2000). The differences in timing of first cleavage are plausibly reflective of inherent differences in transcriptome composition (maternally derived transcripts) between early and late cleaving embryos at the two-cell stage. However, there are no measurable objective molecular markers described to date that can accurately predict the developmental potential of an oocyte prior to cleavage. Investigation of the molecular constituents of oocytes in parallel from two well-established models of reduced developmental competence may reveal common sets of genes or gene families whose mRNA abundance is associated with oocyte competence. Thus, the objectives of the present studies were to use cDNA microarray analysis to identify differences in abundance of specific RNA transcripts in bovine oocytes from adult versus prepubertal animals associated with reduced oocyte competence and to further investigate the relationship of mRNA abundance for select genes of interest (identified from microarray studies) with oocyte competence and early embryonic development.

\section{Materials and Methods}

\section{Materials}

All materials were obtained from Sigma Aldrich unless stated otherwise.

\section{Adult and prepubertal oocyte recovery}

Ovaries from adult and prepubertal (24 weeks of age) animals were collected at local abattoirs and transported to the laboratory in sterile $0.25 \mathrm{M} \mathrm{NaCl}$. Transport time to the laboratory for ovaries collected from adult versus prepubertal animals was approximately 1.5 and $0.5 \mathrm{~h}$ respectively. Upon return to the laboratory, ovaries from adult and prepubertal animals were washed in sterile $0.25 \mathrm{M} \mathrm{NaCl}$, and cumulus-oocyte complexes (COCs) were aspirated from all visible 3-7 $\mathrm{mm}$ follicles, selected (those with more than four compact layers of cumulus cells and homogeneous cytoplasm), washed three to four times in Hepes-buffered hamster embryo culture medium (HECM; $114 \mathrm{mM} \mathrm{NaCl}, 3.2 \mathrm{mM} \mathrm{KCl}, 2 \mathrm{mM}$ $\mathrm{CaCl}_{2} \cdot 2 \mathrm{H}_{2} \mathrm{O}, 0.5 \mathrm{mM} \mathrm{MgCl} \cdot 6 \mathrm{H}_{2} \mathrm{O}, 100 \mu \mathrm{l} / \mathrm{ml}$ MEM (minimum essential medium) non-essential $(10 \times)$ amino acids, $17 \mathrm{mM}$ sodium lactate, $0.1 \mathrm{mM}$ sodium pyruvate, $2 \mathrm{mM} \mathrm{NaHCO}$, $1 \mathrm{mM}$ Hepes, $0.183 \mathrm{mM}$ penicillin-G, $3 \mathrm{mg} / \mathrm{ml}$ BSA; $\mathrm{pH}$ 7.3-7.4; $275 \pm$ $10 \mathrm{mOsm} / \mathrm{kg}$ ) and cumulus cells were completely removed by hyaluronidase $(0.1 \%)$ digestion and repeated pipetting as described previously (Bettegowda et al. 2006). The denuded germinal vesicle stage (GV) oocytes (five pools of 18-20 oocytes from adult and prepubertal animals; cumulus removal confirmed by visual inspection of individual oocytes) and their associated cumulus cells (five pools from same oocytes as mentioned previously) were separately snap-frozen in $100 \mu \mathrm{l}$ lysis solution (RNAqueous Micro Kit, Ambion Inc., Austin, TX, USA) and stored at $-80{ }^{\circ} \mathrm{C}$ until RNA isolation (oocytes only) and subsequent microarray analysis. For real-time PCR analysis, a separate set of samples consisting of five pools of 13-14 oocytes each and matching samples of their associated cumulus cells (from adult and prepubertal animals) were collected and processed as described previously. 


\section{In vitro oocyte maturation}

Germinal vesicle stage COCs (from adult ovaries; collected as described previously) were matured in vitro as described previously (Bettegowda et al. 2006). Briefly, COCs were matured in TCM (tissue culture medium) 199 (supplemented with $0.2 \mathrm{mM}$ sodium pyruvate, $5 \mathrm{mg} / \mathrm{ml}$ gentamicin sulfate, $6.5 \mathrm{mM}$ L-glutamine, $156 \mathrm{nM}$ bovine LH (Sioux Biochemical, Sioux Center, IA, USA), 15.6 nM bovine follicle-stimulating hormone (FSH; Sioux Biochemical), $3.67 \mathrm{nM} 17 \beta$-estradiol, and 10\% (v/v) defined (fetal bovine serum) FBS (Hyclone, Logan, UT, USA)) for $24 \mathrm{~h}$ in groups of 50 in four-well dishes containing $400 \mu \mathrm{l}$ maturation medium at $38.5{ }^{\circ} \mathrm{C}, 5 \% \mathrm{CO}_{2}$ in air with maximum humidity. Oocytes with expanded cumulus were subjected to in vitro fertilization as described later.

\section{In vitro fertilization and embryo culture}

In vitro fertilization and embryo culture were performed as described previously (Bettegowda et al. 2006). Briefly, matured oocytes and sperm $\left(10^{6} \mathrm{sperm} / \mathrm{ml}\right)$ were co-incubated for $20 \mathrm{~h}$ in groups of 50 in four-well dishes containing $400 \mu \mathrm{l}$ fertilization medium $(114 \mathrm{mM} \mathrm{NaCl}$, $25 \mathrm{mM} \mathrm{NaHCO}, 3.2 \mathrm{mM} \mathrm{KCl}, 0.34 \mathrm{mM} \mathrm{NaH}_{2} \mathrm{PO}_{4}$, $0.183 \mathrm{mM}$ penicillin-G, $16.6 \mathrm{mM}$ sodium lactate, $0.5 \mathrm{mM} \mathrm{MgCl} \cdot 6 \mathrm{H}_{2} \mathrm{O}, 2.7 \mathrm{mM} \mathrm{CaCl} 2 \cdot 2 \mathrm{H}_{2} \mathrm{O}, 0.2 \mathrm{mM}$ sodium pyruvate, $6 \mathrm{mg} / \mathrm{ml} \mathrm{BSA}$, and $1.5 \cup$ heparin) at $38.5{ }^{\circ} \mathrm{C}, 5 \% \mathrm{CO}_{2}$ in air with maximum humidity. To separate cumulus cells, the presumptive zygotes were vortexed for $2 \mathrm{~min}$ and washed thrice in Hepes-buffered HECM. Embryo culture was then performed in groups of 50 presumptive zygotes in four-well dishes containing $400 \mu \mathrm{l} \mathrm{KSOM}$ medium (potassium simplex optimization medium; Specialty Media, Phillipsburg, NJ, USA) supplemented with $3 \mathrm{mg} / \mathrm{ml}$ BSA under mineral oil. Culture was carried out at $38.5{ }^{\circ} \mathrm{C}, 5 \% \mathrm{CO}_{2}$ in air with high humidity. Embryos at the 8-16-cell stage were separated $72 \mathrm{~h}$ after fertilization and cultured in fresh KSOM medium supplemented with $3 \mathrm{mg} / \mathrm{ml}$ BSA and $10 \%$ FBS until day 7 . Pronucleus stage embryos (zygotes) were collected at $20 \mathrm{~h}$ post-insemination (hpi), two-cell embryos were collected at $33 \mathrm{hpi}$, four-cell embryos at $44 \mathrm{hpi}$, eight-cell embryos at $52 \mathrm{hpi}, 16$-cell embryos at $72 \mathrm{hpi}$, and morulae at 5 days and blastocysts at 7 days post-insemination. Embryos were processed for RNA isolation as described previously. As a control for the IVF procedure, a pool of embryos from each IVF run were cultured to the blastocyst stage to assess developmental competence of the fertilized eggs. Only embryos collected from controlled experiments with rates of development to blastocyst stage of $>25 \%$ (on day 7 ) were used in the analysis. For each of the embryo stages, five pools of samples ( $n=10$ embryos per pool) were collected from a total of 12 different IVF runs.

For collection of early and late cleaving embryos, pools of early cleaving two-cell embryos $(n=4$ pools of ten embryos each) were collected at $30 \mathrm{~h}$ post-fertilization and processed as described previously. Pools of late cleaving embryos ( $n=4$ pools of ten embryos each) were isolated from the same wells $6 \mathrm{~h}$ later and processed similarly. In each IVF run, a proportion of early and late cleaving two-cell embryos were cultured in separate wells (25 per well) as a control to assess the developmental competence of the fast and slow cleaving embryos. Percentage of development to the blastocyst stage (of oocytes subjected to fertilization) on day 7 was recorded.

\section{RNA extraction}

Total RNA was extracted from each pool of GV oocytes (used in microarray assays) collected from adult and prepubertal animals using the RNAqueous micro kit (Ambion) according to manufacturer's instructions. Total RNA from remaining samples was extracted with the same kit, but with slight modifications. Before RNA extraction, each sample was spiked with $250 \mathrm{fg}$ green fluorescent protein (GFP) synthetic RNA as an exogenous control for RNA recovery and efficiency of cDNA synthesis (Bettegowda et al. 2006). Residual genomic DNA in all extracted samples was removed by DNase I digestion (Ambion). RNA was eluted twice from the silica-based microfilter cartridge using $10 \mu \mathrm{l}$ volume of prewarmed $\left(75^{\circ} \mathrm{C}\right)$ elution solution according to manufacturer's instructions. The RNA from each pool of oocytes collected from adult and prepubertal animals was divided into two $10 \mu \mathrm{l}$ aliquots. One aliquot of extracted total RNA was used for cDNA microarray analysis. Similarly, total RNA for real-time PCR analysis extracted from GV oocytes collected from prepubertal and adult animals, their matching cumulus cells, and in vitro produced early bovine embryos was eluted in $20 \mu$ l eluent, but only $10 \mu \mathrm{l}$ was utilized for each cDNA synthesis reaction.

\section{Total RNA amplification and cDNA microarray analysis}

Total RNA $(10 \mu \mathrm{l})$ from the pools of oocytes $(n=5)$ collected from adult and prepubertal animals for microarray experiments was amplified using the RiboAmp kit (Arcturus, Mountain View, CA, USA) using previously validated procedures (Patel et al. 2005). The quality and quantity of the amplified RNA generated were estimated using a u.v. spectrophotometer (Beckman Instruments, Fullerton, CA, USA), and the Bioanalyzer 2100 RNA 6000 nanochip (Agilent Technologies, Walbronn, Germany). Only those amplification reactions yielding amplified RNA of consistent size range and quantity across samples were utilized in subsequent microarray experiments.

Two color microarray experiments were conducted as described previously (Patel et al. 2005) using a bovine 
cDNA array containing expressed sequence tags (ESTs) representing approximately 15200 unique genes (Suchyta et al. 2003). A total of $15 \mu \mathrm{g}$ amplified RNA from oocytes samples harvested from adult and prepubertal animals were used for cDNA synthesis and labeling (Patel et al. 2005). Hybridizations were performed on duplicate slides for each pair of samples (prepubertal versus adult) and incorporated a dye swap ( $n=10$ slides total).

\section{RT and quantitative real-time PCR}

Total RNA $(10 \mu \mathrm{l})$ from each sample for real-time PCR analysis was utilized for RT using oligo dT (15) primers as described elsewhere (Bettegowda et al. 2006). A $10 \mu \mathrm{l}$ aliquot of RNA from early bovine embryos was also reverse transcribed as described previously using random hexamers (Bettegowda et al. 2006). After termination of cDNA synthesis, each RT reaction was then diluted with nuclease-free water (Ambion) to a final volume of $100 \mu \mathrm{l}$.

The quantification of all gene transcripts (follistatin, $\beta B$, and $\beta A$ subunits of inhibin/activin, $\alpha$ subunit of inhibin, GFP, and 18S rRNA) was done by real-time quantitative RT-PCR using SYBR Green PCR Master Mix (Applied Biosystems, Foster City, CA, USA). The relative quantification method was utilized as described in detail elsewhere (Livak \& Schmittgen 2001). Primers were designed using the Primer Express program (Applied Biosystems) and derived from bovine sequences found in GenBank (see Table 1). The amplicon size for each of the genes studied ranged from 80 to $150 \mathrm{bp}$. A primer matrix was performed for each gene tested to determine optimal primer concentrations. Each reaction mixture consisted of $2 \mu \mathrm{l}$ cDNA, $1.5 \mu \mathrm{l}$ each of forward $(5 \mu \mathrm{M})$ and reverse primers $(5 \mu \mathrm{M}), 7.5 \mu \mathrm{l}$ nuclease-free water, and $12.5 \mu \mathrm{l}$ SYBR Green PCR Master Mix in a total reaction volume of $25 \mu \mathrm{l}$ (96-well plates). Reactions were performed in duplicate for each sample in an ABI Prism 7000 Sequence Detection System (Applied Biosystems). Two non-template control samples were included on each plate for each primer set. Specificity of amplification with each primer set in each assay was confirmed by melting curve analysis. The thermal cycler program consisted of 40 cycles of $95^{\circ} \mathrm{C}$ for $15 \mathrm{~s}$ and $60{ }^{\circ} \mathrm{C}$ for $1 \mathrm{~min}$. For real-time PCR experiments, amounts of mRNAs of interest were normalized relative to an exogenous control (GFP) to control for differences in RNA recovery and efficiency of RT (Bettegowda etal. 2006) and also separately normalized relative to abundance of an endogenous control (18S rRNA) to account for differences in RNA concentrations between samples. The mean sample threshold cycle (CT) and mean endogenous/ exogenous control CT for each sample were calculated from duplicate wells. The mean CT of the control was then subtracted from the CT of samples to give the $\Delta C T$. In each experiment, one of the experimental samples served as a control (calibrator). Subsequently, $\Delta C T$ of target sample was then subtracted from the calibrator $\Delta C T$. The relative amounts of target gene expression for each sample were then calculated using the formula $2^{-(\Delta \Delta C T)}$ (Livak \& Schmittgen 2001). Copies of $18 \mathrm{~S}$ rRNA were also quantified using standard curve technology for absolute quantification (Whelan et al. 2003) as an index for differences in amounts of total RNA between samples of interest.

\section{Data analysis}

For microarray experiments, estimates of false discovery rate $(F D R)$ and differentially expressed genes $(F D R=5 \%)$ were identified using the significance analysis of microarrays program (Tusher et al. 2001). Differences in ratios of $\mathrm{Cy} 3 / \mathrm{Cy} 5<0.7(P<0.05 ; \mathrm{FDR}=5 \%)$ or Cy3/Cy5 $>1.3 \quad(P<0.05 ; \mathrm{FDR}=5 \%)$ were considered significant. Initial annotation and gene symbols for features on the array were obtained using the Gene Links toolkit (http://cafg.msu.edu).

Ontological classification and further annotation of genes encoding for transcripts showing differences in abundance in adult versus prepubertal oocytes were performed using the Database for Annotation, Visualization and Integrated Discovery (Dennis et al. 2003). Identification of biological themes (overrepresented genes) within lists of genes showing greater mRNA

Table 1 Sequence of primers used for real-time PCR.

\begin{tabular}{|c|c|c|}
\hline Gene & GenBank Accession number & Sequence \\
\hline Follistatin & BF774514 & $\begin{array}{l}\text { F: 5'-CAGAGCTGCAAGTCCAGTACCA-3' } \\
\text { R: 5'-CATGTAGAGCTGCCTGGACAGA-3' }\end{array}$ \\
\hline Inhibin $\alpha$ & BE721322 & $\begin{array}{l}\text { F: 5'-CCTCGGATGGAGGTTACTCTTTT-3' } \\
\text { R: } 5^{\prime} \text {-CGGGATTCCCTTAGATGCAA-3' }\end{array}$ \\
\hline Inhibin $\beta A$ subunit & AW658434 & $\begin{array}{l}\text { F: 5'-GAGCAGTCGCACAGACCTTTC-3' } \\
\text { R: 5'-CCGGTGAGGATGGTCTTCAG-3' }\end{array}$ \\
\hline Inhibin $\beta B$ subunit & AW669304 & $\begin{array}{l}\text { F: 5'-GCATCTCCAGAATGCCTTCAC-3' } \\
\text { R: } 5^{\prime} \text {-GTGGAAATGACTCTTATGCAATGG-3' }\end{array}$ \\
\hline GFP & - & $\begin{array}{l}\text { F: 5'-CAACAGCCACAACGTCTATATCATG-3' } \\
\text { R: 5'-ATGTTGTGGCGGATCTTGAAG-3' }\end{array}$ \\
\hline $18 \mathrm{~S}$ rRNA & BC102293 & $\begin{array}{l}\text { F:5'-GTGGTGTTGAGGAAAGCAGACA-3' } \\
\text { R: } 5^{\prime} \text {-TGATCACACGTTCCACCTCATC-3' }\end{array}$ \\
\hline
\end{tabular}


abundance in prepubertal and adult oocytes was performed using EASE expression analysis systematic explorer; (Hosack et al. 2003) with a FDR of $10 \%$. Nonredundant annotation classes with an EASE score of less than $5 \%$ are depicted.

For real-time PCR experiments, differences in abundance of specific transcripts of interest between adult and prepubertal oocytes and cumulus cell samples, early versus late cleaving embryos, and across stages of early embryonic development were analyzed by ANOVA using the General Linear Models procedure of SAS. Mean comparisons were performed when appropriate using Tukey's test.

\section{Results}

cDNA microarray analysis of RNA transcript profiles for oocytes collected from adult versus prepubertal animals

Microarray experiments revealed a significant number of genes encoding for transcripts of different abundance in GV oocytes harvested from adult versus prepubertal animals (see Supplementary data, Table 1). A total of 193 genes encoding for transcripts displaying greater mRNA abundance in adult oocytes and 223 genes encoding for transcripts displaying greater mRNA abundance in compromised prepubertal oocytes were detected $(P<0.05 ; \mathrm{FDR}=5 \%)$. Of the 193 bovine genes encoding for transcripts that were of greater abundance in adult versus prepubertal oocytes, 159 were annotated and 153 classified into ontology categories listed (Fig. 1). Of the 223 genes encoding for transcripts that were of greater abundance in prepubertal versus adult oocytes, 201 were annotated and 196 ontologically classified (Fig. 1). Nonredundant overrepresented gene categories (appearing more often in gene lists than would be predicted based on distribution among all genes represented on the array) in above gene lists are depicted in Table 2. Genes in the regulation of hormone secretion ontology category were found to overrepresented in the adult oocyte samples with lowest EASE score and given their documented biological activity, were selected for further analysis. Such genes encode for the $\beta A$ and $\beta B$ subunits of inhibin/activin and their binding protein, follistatin. A difference in hybridization intensity of $2.5,2.4$, and 1.7 for the $\beta A$ subunit, follistatin, and the $\beta B$ subunit respectively, corresponding to potentially higher mRNA abundance in adult versus prepubertal oocytes was observed in microarray studies (Supplementary data, Table 1).

\section{Relative abundance of inhibin/activin and follistatin transcripts in adult versus prepubertal oocytes and cumulus cells}

Real-time PCR analysis using a set of samples distinct from those used in microarray experiments confirmed lower amounts of mRNA for above genes (follistatin, $\beta B$, and $\beta A$ subunits of inhibin/activin) in oocytes collected from prepubertal animals (Fig. 2). Differences in abundance of mRNA for the $\alpha$ subunit of inhibin were also examined to give a more complete picture of phenotypic differences in mRNA abundance for inhibin/ activin subunits in oocytes collected from adult versus prepubertal animals, even though $\alpha$ subunit mRNA abundance was not significantly different in microarray studies (data not shown). The relative abundance of $m R N A s$ for the $\beta B$ and $\beta A$ subunits of inhibin/activin and for follistatin was approximately three- to fivefold higher in oocytes from adult versus prepubertal animals $(P<0.002)$, but no difference in $\alpha$ subunit mRNA abundance was observed. No difference in abundance of $18 \mathrm{~S}$ rRNA was detected in oocyte samples from adult versus prepubertal animals (data not shown), further confirming that differences in amounts of follistatin, $\beta A$, and $\beta B$ subunit RNAs observed are not merely due to differences in abundance of total RNA in the two populations of oocytes. Differences in abundance of mRNA for follistatin and the $\beta B$ subunit of inhibin/activin were specific to the oocyte compartment of COCs collected from adult versus prepubertal animals. There was no difference in mRNA abundance for the $\alpha$ and $\beta B$ subunits of inhibin/activin and for follistatin in matching cumulus cells collected from oocytes harvested from adult versus prepubertal animals, but $\beta$ A subunit mRNA was slightly higher $(P<0.05)$ in the cumulus cells surrounding oocytes collected from adult animals (Fig. 3).

\section{Relative abundance of inhibin/activin and follistatin transcripts in early versus late cleaving two-cell bovine embryos}

Given lower abundance of follistatin, $\beta B$, and $\beta A$ subunit mRNAs observed in oocytes collected from prepubertal animals (poor oocyte competence) versus adult animals, we hypothesized that abundance of oocyte-derived transcripts for follistatin, $\beta B$, and $\beta A$ subunits would be lower in late cleaving (reduced development to blastocyst stage) versus early cleaving two-cell stage bovine embryos. Early cleaving embryos had a greater blastocyst yield $(40 \pm 4 \%)$ than their late cleaving counterparts $(10 \pm 3 \%)$. Greater mRNA abundance for follistatin, but not for the $\beta B$ and $\beta A$ subunits of inhibin/activin, or the $\alpha$ subunit of inhibin was observed in early cleaving embryos compared with late cleaving embryos $(P<0.05$; Fig. 4$)$. No differences in abundance of $18 \mathrm{~S}$ rRNA were detected in early versus late cleaving embryos (data not shown), indicating that differences in amounts of follistatin, $\beta A$, and $\beta B$ subunit mRNAs observed were not due to differences in abundance of total RNA in the two populations of embryos. 


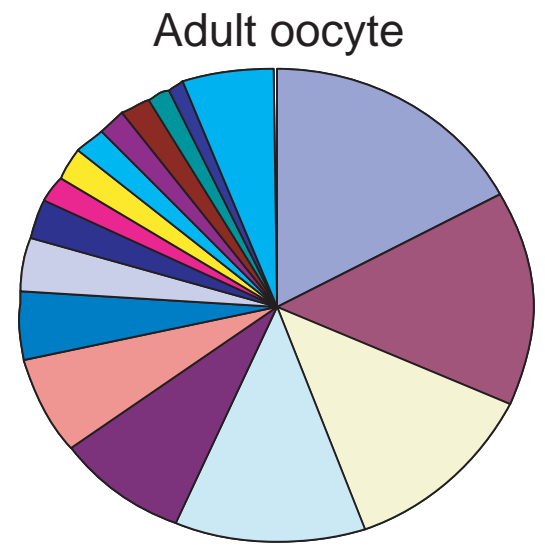

physiological process (18)

cell (14)

catalytic activity (9)

extracellular (5)

cellular component unknown (3)

enzyme regulator activity (2)

structural molecule activity (2)

$\square$ transporter activity (2)

$\square$ unclassified (6)

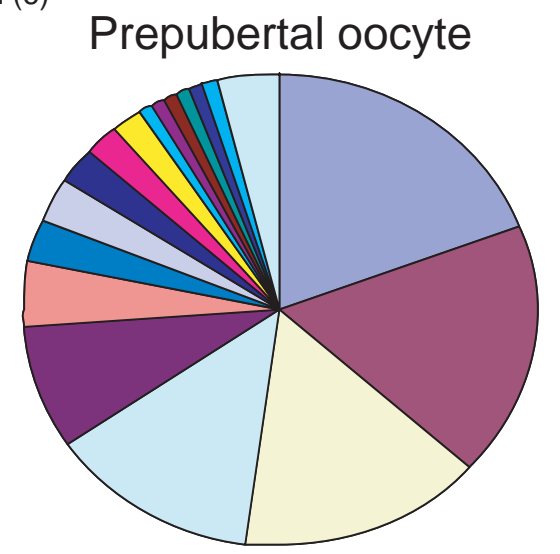

$\square$ unclassified (6) $\square$ binding (15)

$\square$ cellular process (13)

$\square$ development (7)

$\square$ signal transducer activity (4)

biological process unknown (2)

$\square$ regulation of biological process (2)

molecular function unknown (2)

- transcription regulator activity (1)

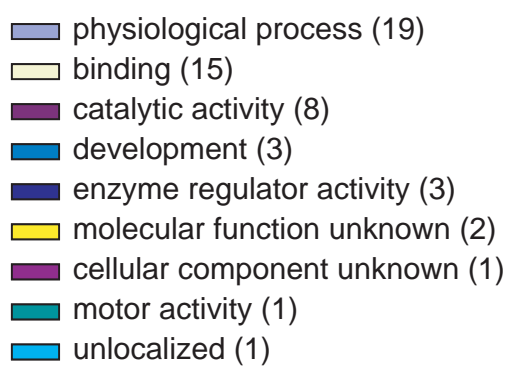

$\square$ cell (17)

$\square$ cellular process (13)

$\square$ transporter activity (4)

$\square$ signal transducer activity (3)

$\square$ transcription regulator activity (2)

$\square$ biological process unknown (1)

ש extracellular (1)

w structural molecule activity (1)

$\square$ unclassified (4)
Figure 1 Ontological classifications of genes encoding for transcripts of greater abundance in germinal vesicle stage oocytes collected from adult (top) and prepubertal animals (bottom). Of the 193 and 223 bovine genes encoding for transcripts displaying greater abundance in oocytes collected from adult and prepubertal animals, 159 and 201 were annotated and 153 and 196 were classified respectively into ontology categories listed for the two oocyte populations. Numbers in parentheses indicate percentage of total number of genes with transcripts of greater abundance for given population of oocytes that are represented in each ontology category.

\section{Relative abundance of inhibin/activin and follistatin transcripts during early embryogenesis in vitro}

Given observed association of follistatin transcript abundance with oocyte competence, we then investigated the temporal regulation of mRNA abundance for above genes during early embryonic development in vitro. Changes in relative abundance of polyadenylated transcripts for follistatin, $\beta A$ and $\beta B$ subunits of inhibin/activin, and the $\alpha$ subunit of inhibin in embryos collected at the pronuclear, two-, four-, eight-, sixteencell, morula and blastocyst stages are illustrated in Fig. 5A. Follistatin, the $\beta \mathrm{B}$ subunit of inhibin/activin, and the $\alpha$ subunit of inhibin transcripts exhibited similar temporal changes in abundance, where mRNA 
Table 2 EASE analysis of over-represented genes.

\begin{tabular}{|c|c|c|c|c|}
\hline Sample & System & Gene category & Ease score & Gene symbol \\
\hline \multirow[t]{3}{*}{ Adult oocyte } & GO biological processes & $\begin{array}{l}\text { Regulation of } \\
\text { hormone secretion }\end{array}$ & $1.84 \times 10^{-3}$ & FST, INHBA, INHBB \\
\hline & & $\begin{array}{l}\text { Macromolecule } \\
\text { biosynthesis }\end{array}$ & $9.78 \times 10^{-3}$ & $\begin{array}{l}\text { ATIC, ATP5B, C20ORF155, EEF1A1, GCNT1, HSPB1, } \\
\text { INHBA, INHBB, RPL10A, RPL9, RPS3A, SCD, TPI1 }\end{array}$ \\
\hline & GO molecular function & Protein binding & $1.72 \times 10^{-2}$ & $\begin{array}{l}\text { CDK6, COTL1, CTNNBIP1, FLNA, FUS, INHBA, } \\
\text { INHBB, JUP, PFN1, PRSS11, RIPK3, RTN3, SPARC, } \\
\text { TPM1, TWSG1, VIM }\end{array}$ \\
\hline $\begin{array}{l}\text { Prepubertal } \\
\text { oocyte }\end{array}$ & GO cellular component & Intracellular & $2.08 \times 10^{-2}$ & $\begin{array}{l}\text { APLP2, B4GALT5, C1ORF16, CCNB2, CTNND1, } \\
\text { DIAPH1, DVL2, EIF3S4, FLJ10774, FRAP1, GBA, } \\
\text { GNAI1, GTF2F1, HNRPF, INPP1, ISGF3G, KEAP1, } \\
\text { KHSRP, KIF3C, MBNL3, MGAT1, MLL3, MSX1, } \\
\text { MYH1, NAPA, NDUFV2, NFKBIA, ODC1, PEG10, } \\
\text { POLS, PPARBP, PRC1, PRDM2, PRDX5, PRKAR1A, } \\
\text { PSTPIP1, RASA1, REV1L, RTN3, SEC14L1, SPOP, } \\
\text { STAR, TAP2, TOP1, TPM2, ZFYVE1 }\end{array}$ \\
\hline
\end{tabular}

GO, gene ontology.

abundance for each gene remained low until the 16-cell stage when a significant $(P<0.05)$ increase was detected (12-40 fold). The increase in relative abundance of the three transcripts at the 16-cell stage was transient, as amounts of mRNA were significantly decreased at the morula and blastocyst stages (Fig. 5A). Similar results ( $P<$ 0.05 ) were obtained when abundance of total transcripts for follistatin, $\beta \mathrm{A}$ and $\beta \mathrm{B}$ subunits of inhibin/activin, and the $\alpha$ subunit of inhibin was determined using cDNA generated with random hexamers (Fig. 5B). Data depicted in Fig. 5A and $B$ were normalized relative to abundance of $18 \mathrm{~S}$ rRNA to account for differences in RNA content of embryos at various stages of development.

\section{Discussion}

In the present study, differences in RNA transcript profiles associated with competence of oocytes harvested from prepubertal versus adult animals were examined using a functional genomics approach and novel information on oocyte transcripts potentially associated with developmental competence identified. Four distinct biological themes (based on EASE analysis) were delineated from gene lists resulting from microarray studies, which each form a foundation for future investigation. Based on EASE score and documented paracrine and autocrine reproductive roles of genes represented in the regulation of hormone secretion category, the dynamic regulation of mRNA for a subset of the transforming growth factor (TGF) $\beta$ superfamily ( $\beta \mathrm{A}, \beta \mathrm{B}$, and $\alpha$ subunits of inhibi$\mathrm{n}$ /activin) and their binding protein (follistatin) was further investigated in two well-established, albeit different models of oocyte competence in cattle.

To our knowledge, the present report is the first to document an association of follistatin mRNA abundance with oocyte competence and a confirmed association of mRNA abundance for a known gene with oocyte competence in two established model systems. Furthermore, a transient upregulation of follistatin and inhibin/activin subunit mRNAs $(\alpha, \beta B)$ was observed at the 16-cell stage of early embryonic development, presumably resulting from new transcription from the embryonic genome. These results indicate that apart from the reported role of follistatin in regulating activin activity (Knight \& Glister 2001, Phillips 2005), relative amounts of follistatin mRNA may be predictive of oocyte competence and suggest that follistatin may play a role in bovine early embryonic development.

A total of 193 and 223 transcripts showing greater abundance in oocytes collected from adult and prepubertal animals respectively were identified from microarray experiments. Given that $>15000$ unique genes were represented on the bovine cDNA microarray utilized in the present studies (Suchyta et al. 2003), results suggest that differences in transcript abundance were not
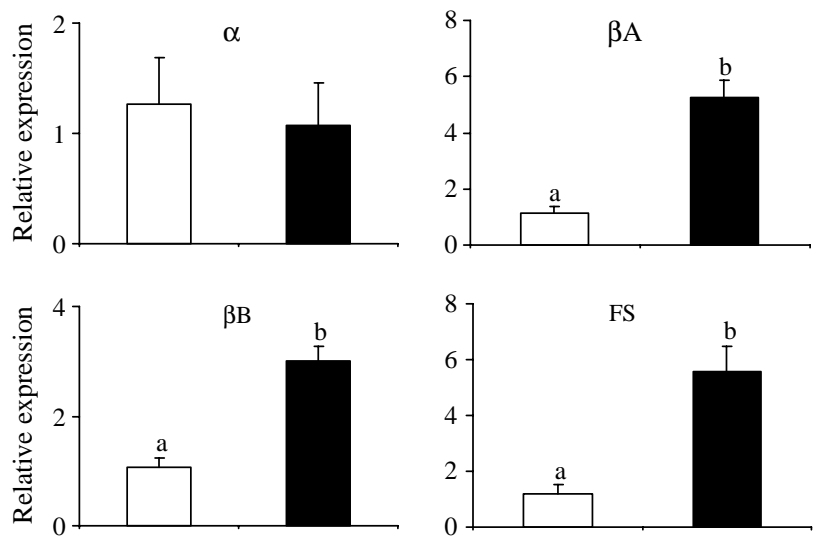

Figure 2 Quantitative real-time RT-PCR analysis of $\alpha$ subunit of inhibin $(\alpha), \beta A(\beta A)$, and $\beta B(\beta B)$ subunits of inhibin/activin and follistatin (FS) transcripts in oocyte samples collected from prepubertal (white bar) and adult (black bar) animals ( $n=5$ each). Data were normalized relative to abundance of $18 \mathrm{~S}$ rRNA (endogenous control) and are shown as mean \pm S.E.M. Similar results were obtained when data were normalized relative to exogenous control RNA (GFP) to account specifically for differences in RNA recovery and efficiency of reverse transcription (data not shown). Time points within each panel without common superscripts differ, $a, b=P<0.002$. 

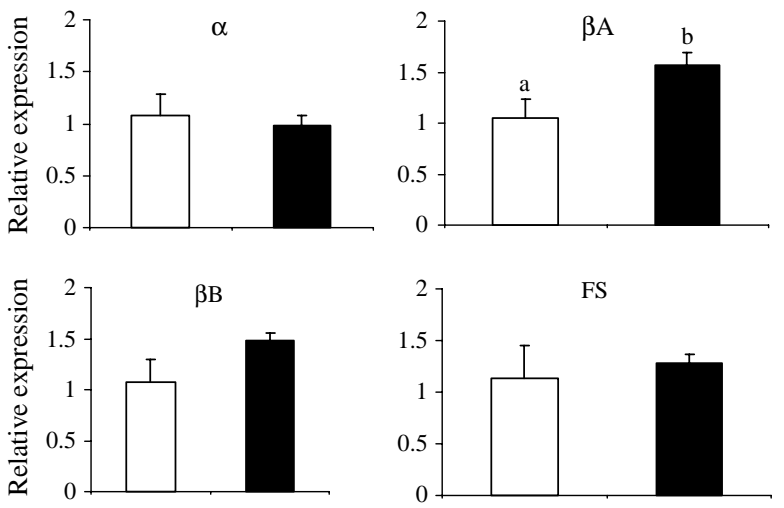

Figure 3 Quantitative real-time RT-PCR analysis of $\alpha$ subunit of inhibin $(\alpha), \beta A(\beta A)$, and $\beta B(\beta B)$ subunits of inhibin/activin and follistatin (FS) transcripts in matching cumulus cell samples harvested from oocytes collected from prepubertal (white bar) and adult (black bar) animals $(n=5$ each). Data were normalized relative to abundance of endogenous control (18S rRNA) and are shown as mean \pm s.E.M. Time points within each panel without common superscripts differ, $\mathrm{a}, \mathrm{b}=P<0.05$.

solely due to differences in total RNA abundance between the two populations of oocytes, an observation that was also confirmed based on no observed difference in $18 \mathrm{~S}$ rRNA abundance in adult versus prepubertal oocytes. Microarray approaches have been applied previously in mice to identify differences in RNA transcript profiles associated with oocyte aging (Hamatani et al. 2004) and development in vitro versus in vivo (Pan et al. 2005). In both cases, statistically significant differences in transcript abundance were observed for a relatively small percentage of genes $(<5 \%)$. Thus, the numbers of transcripts of greater abundance in adult and prepubertal oocytes detected in the present microarray
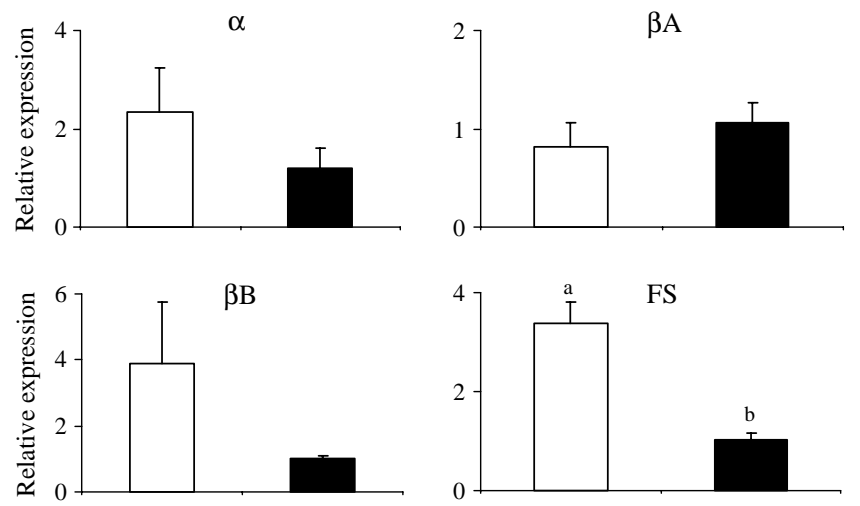

Figure 4 Quantitative real-time RT-PCR analysis of $\alpha$ subunit of inhibin $(\alpha), \beta A(\beta A)$, and $\beta B(\beta B)$ subunits of inhibin/activin and follistatin (FS) transcripts in samples of early (white bar) and late (black bar) cleaving bovine two-cell embryos ( $n=4$ each). Data were normalized relative to abundance of $18 \mathrm{~S}$ rRNA (endogenous control) and are shown as mean \pm S.E.M. Similar results were obtained when data were normalized relative to exogenous control RNA (GFP) to account specifically for differences in RNA recovery and efficiency of reverse transcription (data not shown). Time points within each panel without common superscripts differ, $a, b=P<0.05$. studies seems reasonable given the rigid analysis criteria employed. Future studies will be required to elucidate the association of additional transcripts identified in previously described microarray experiments with oocyte competence in other models and the potential functional and diagnostic significance of our results.

The TGF- $\beta$ (inhibin/activin) family members and their binding protein follistatin play key roles in folliculogenesis and an association with oocyte maturation is well established (Knight \& Glister 2001, Phillips 2005). We acknowledge that results of the present studies merely establish an association of follistatin mRNA abundance with oocyte competence in the two model systems examined and do not prove a functional role for follistatin and/or inhibins/activins in oocyte competence. A number of previous studies have investigated the effect of supplementation with exogenous activin, inhibin, and follistatin in vitro on early embryonic development (Izadyar et al. 1996, Yoshioka \& Kamomae 1996, Stock et al. 1997, Silva \& Knight 1998, Yoshioka et al. 1998) and with mixed results. Stock et al. (1997) reported that supplementation of media with inhibin, activin, or the combination during in vitro bovine oocyte maturation significantly increased cleavage rates postfertilization. Based on these results, they concluded that inhibin and activin may be important in the acquisition of oocyte competence. However, an antagonistic relationship between inhibin and activin is essential to the control of pituitary $\mathrm{FSH}$ release and to normal gonadal function (Knight \& Glister 2003, Phillips 2005). Thus, it is interesting that both inhibin and activin were able to unvaryingly influence cleavage rates following supplementation during oocyte maturation (Stock et al. 1997). Other independent studies found no effect of inhibin and activin supplementation during in vitro oocyte maturation on subsequent development to the blastocyst stage following in vitro fertilization (Van Tol et al. 1994, Izadyar et al. 1996, Silva \& Knight 1998). Similar findings of no substantial effect on postfertilization cleavage rates were also reported following follistatin supplementation during in vitro oocyte maturation (Silva \& Knight 1998). On the other hand, activin supplementation during in vitro embryo culture was reported to increase blastocyst yield, whereas an inhibitory effect of follistatin was noted (Yoshioka \& Kamomae 1996, Yoshioka et al. 1998). It remains to be elucidated whether endogenous production of above growth factors compromised effects of exogenously supplemented growth factors and thus complicated interpretation of the physiological role of endogenous activin, inhibin, and/or follistatin. Secondly, it remains to be verified if time of administration coincided with the biologically relevant stages of development when oocyte-derived endogenous inhibin, activin, and follistatin potentially act. Hence, it will be important to delineate the stage-specific regulatory role of endogenous oocyte-derived inhibin, activin, and follistatin to 

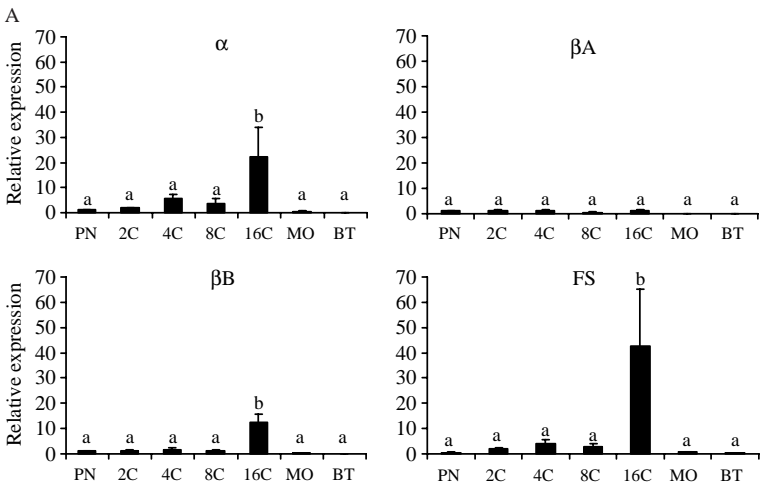
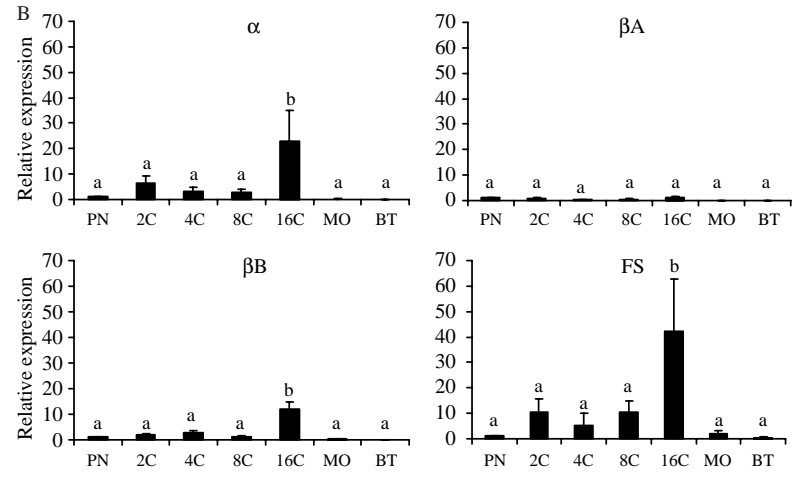

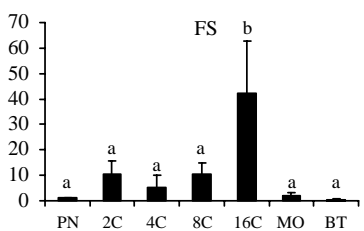

Figure 5 Quantitative real-time RT-PCR analysis of $\alpha$ subunit of inhibin $(\alpha), \beta A(\beta A)$, and $\beta B(\beta B)$ subunits of inhibin/activin and follistatin (FS) transcripts in samples of in vitro derived bovine embryos collected at pronucleus (PN), two-cell (2C), four-cell (4C), eight-cell (8C), sixteen-cell (16C), morula (MO), and blastocyst (BT) stages ( $n=5$ each). (A) Differences in abundance of polyadenylated transcripts for genes of interest (RNA reverse transcribed with oligo $\mathrm{dT}_{(15)}$ primers) at specific stages of early embryonic development. (B) Differences in abundance of total transcripts for genes of interest (RNA reverse transcribed with random hexamers) at specific stages of early embryonic development. Data were normalized relative to abundance of $18 \mathrm{~S} r R N A$ (endogenous control) and are shown as mean \pm s.E.M. Similar results were obtained when data were normalized relative to exogenous control RNA (GFP) to account specifically for differences in RNA recovery and efficiency of reverse transcription (data not shown). Time points within each panel without common superscripts differ, $P<0.001$.

facilitate interpretations of earlier studies employing exogenously supplemented treatments.

To our knowledge, no studies have addressed the relationship between endogenous follistatin production and early embryonic development in cattle. Matzuk (1995) utilizing activin- and follistatin-deficient mice proposed that low doses of follistatin may actually play an agonistic role in the activin response. Low levels of follistatin could thus increase the bioavailability of activin rather than neutralize its actions (Silva \& Knight 1998). The latter is substantiated by the fact that administration of lower doses of follistatin to COCs increased their developmental potential and did not antagonize the effects of activin A (Silva \& Knight 1998). Thus, a potential functional association of oocyte-derived follistatin with oocyte competence is supported by results of the present study, but additional experiments are necessary to determine cause-effect relationships.

The oocyte and its surrounding somatic cells are interdependent in regulation of growth and development of the oocyte and ovarian follicle (Eppig et al. 2002, Matzuk et al. 2002). Follistatin and inhibin/activin mRNAs and protein are detectable in the germ and somatic cell compartments of antral follicles (Izadyar et al. 1998, Silva et al. 2003, 2004). Moreover, there is ample evidence that germ cell-derived factors influence secretion of a plethora of substances by the surrounding somatic cells, including TGF- $\beta$ family members (Eppig 1991, Eppig et al. 2002, Matzuk et al. 2002). Two recent studies have described cyclooxygenase-2, hyaluronic acid synthase-2, gremlin, and pentraxin- 3 expression in the cumulus cells as potential markers of the quality of the enclosed oocyte (McKenzie et al. 2004, Zhang et al. 2005). However, neither of the latter studies elaborated whether the same described genes were correspondingly altered in the germ cells encompassed by these somatic cells, because such experiments would require destruction of the oocyte. To our knowledge, this study is the first to correlate altered mRNA abundance between the germ and somatic cells in a known model of developmentally compromised oocytes. Abundance of mRNA for the $\beta A$ subunit of inhibin/activin was higher both in the oocyte and the cumulus cell compartment of COCs collected from adult versus prepubertal animals. However, transcript abundance for follistatin and the $\alpha$ and $\beta B$ subunits of inhibin/activin was similar in cumulus cells surrounding the same oocytes collected from prepubertal versus adult animals where differences in oocyte mRNA abundance for follistatin and the $\beta B$ subunit were observed. This may suggest that although follistatin and activins/inhibins may be necessary for the synchronized development of germ and somatic cells (Knight \& Glister 2001, Phillips 2005), their overall regulation in the two cell types is generally distinct.

It is well known that transcription in bovine oocytes declines to very low levels upon attainment of full size (approximately $120 \mu \mathrm{m}$ ) in a follicle of about $3 \mathrm{~mm}$ in diameter (Fair et al. 2002), and does not reinitiate at significant levels until the maternal-zygotic transition (Telford et al. 1990, Memili \& First 1998, 2000). Therefore, prior to this stage, post-fertilization development is dependent on timely translation of maternally derived oocyte mRNAs. Since the maternal-zygotic transition and initiation of significant new transcription are characteristic of later stages (8-16 cell) of embryonic development in cattle (Telford et al. 1990, Memili \& First 1998, 2000), potential markers of high-quality oocytes are also likely to be of greater abundance in early versus late cleaving two-cell stage bovine embryos. We thus explored the association of mRNAs for follistatin, the $\beta A$ and the $\beta B$ subunits of inhibin/activin, and the $\alpha$ subunit of inhibin with time of first cleavage in this model of 
oocyte competence. After IVF, early cleaving embryos have enhanced competence to reach the blastocyst stages as compared with their later cleaving counterparts (McKiernan \& Bavister 1994, Sakkas et al. 1998, Shoukir et al. 1998). In our study, the early cleaving control embryos attained higher rates of development to the blastocyst stage in comparison with late cleaving embryos, in agreement with earlier reports (Lonergan et al. 2003a). In addition, increased abundance of follistatin mRNA was evident in early versus late cleaving bovine embryos, similar to the relationship observed in oocytes collected from adult versus prepubertal animals. Although the relationship between the kinetics of early embryonic cleavage and subsequent development have been reported in several species (McKiernan \& Bavister 1994, Sakkas et al. 1998, Lonergan et al. 2003b), the mechanisms influencing the kinetics of initial early cleavage divisions are not clear. However, all authors do agree that time of first cleavage is linked to the intrinsic quality of the oocyte (Plante et al. 1994, Brevini et al. 2002, Rizos et al. 2002, Lonergan et al. 2003b, Gutierrez-Adan et al. 2004). Furthermore, while follistatin is best known for its ability to bind activin with a high affinity, there is evidence of additional roles for follistatin independent of activin binding and important functional roles during development. For example, follistatin binds to bone morphogenetic proteins (BMPs) and the BMPs are also important for oocyte and embryonic development (Fainsod et al. 1997, lemura et al. 1998). In addition, in Xenopus, follistatin is reported to act as an organizer factor during early embryogenesis (lemura et al. 1998). Thus, further studies will be required to determine the functional significance of alterations in follistatin transcript abundance to oocyte competence and time of first cleavage and the mechanisms involved.

An association of mRNA abundance for several other genes with time of first cleavage has been established previously. Gutierrez-Adan et al. (2004) reported that mRNAs for stress-induced genes, such as sarcosine oxidase, mitochondrial Mn-superoxide dismutase, apoptosis regulator bax- $\alpha$, interferon $\tau$, and glucose- 6 phosphate dehydrogenase are more abundant in slow developing embryos, but the authors previously noted that culture conditions significantly altered mRNA abundance for the same stress-associated genes (Lonergan et al. 2003b). Greater mRNA abundance for histone $\mathrm{H} 3$ and the preimplantation embryo development (Ped) genes has been observed in early versus late cleaving twocell bovine embryos (Fair et al. 2004a, 2004b), as has greater $\mathrm{mRNA}$ abundance for isocitrate dehydrogenase, histone $\mathrm{H} 2 \mathrm{~A}$, and $\mathrm{YY} 1$ - and E4TF1-associated factor 1 (Dode et al. 2006). However, to our knowledge, an association of oocyte mRNA abundance for above genes with developmental competence has not been confirmed in additional experimental models. This study is the first to show that follistatin mRNA abundance in oocytes is regulated and associated with oocyte competence in two well-described experimental model systems. Therefore, our results suggest that maternally derived follistatin may play a regulatory role in bovine early embryogenesis.

This study also demonstrated that follistatin, $\beta B, \beta A$, and $\alpha$ subunits of inhibin/activin mRNAs are dynamically regulated during early embryogenesis. During the early cleavage stages up until zygotic genome activation and initiation of new transcription, embryonic development is entirely dependent on maternal mRNAs and proteins synthesized and stored during oogenesis (Telford et al. 1990, Memili \& First 1998, 2000) In the present study, mRNA abundance for follistatin, the $\beta B$ subunit of inhibin/ activin, and the $\alpha$ subunit of inhibin remained low until the 16-cell stage, where a significant increase in mRNA abundance for above genes was observed. This rapid increase in mRNA abundance at the 16-cell stage is likely due to new transcription of such genes from the embryonic genome and not due to post-transcriptional modification of existing RNA stores, since a similar temporal upregulation was observed when both total and polyadenylated transcripts for genes of interest were quantified.

Interestingly, Majerus et al. (2000) found that a significant proportion of calf oocyte-derived embryos arrested development before the nine-cell stage and those that developed to the blastocyst stage had a longer lag phase preceding the major onset of zygotic genome activation than oocytes derived from adult animals. Similar results were reported by Camargo et al. (2005). Thus, it is plausible that increased mRNA abundance for follistatin, the $\beta B$ subunit of inhibin/activin, and the $\alpha$ subunit of inhibin at the 16 -cell stage could be associated with important developmental events, including compaction of blastomeres and subsequent cavitation. However, the functional significance of observed changes in mRNA abundance remains to be determined.

\section{Acknowledgements}

Supported by the Rackham Foundation, the Michigan State University Office of the Vice President for Research and Graduate Studies and the Michigan Agricultural Experiment Station. The authors wish to thank Dr Michael VandeHaar for providing ovaries from prepubertal animals and Meher Adithya Bandela for help with microarray data analysis. The authors also wish to thank Sue Sipkovsky and other personnel of the MSU CAFG for technical assistance. The authors declare that there is no conflict of interest that would prejudice the impartiality of this scientific work.

\section{References}

Armstrong DT 2001 Effects of maternal age on oocyte developmental competence. Theriogenology 55 1303-1322.

Bettegowda A, Patel OV, Ireland JJ \& Smith GW 2006 Quantitative analysis of messenger RNA abundance for ribosomal protein L-15, cyclophilin-A, phosphoglycerokinase, $\beta$-glucuronidase, glyceraldehyde 3 -phosphate dehydrogenase, $\beta$-actin and histone $\mathrm{H} 2 \mathrm{~A}$ during bovine oocyte maturation and early embryogenesis in vitro. Molecular Reproduction and Development 73 267-278. 
Brevini TA, Lonergan P, Cillo F, Francisci C, Favetta LA, Fair T \& Gandolfi F 2002 Evolution of mRNA polyadenylation between oocyte maturation and first embryonic cleavage in cattle and its relation with developmental competence. Molecular Reproduction and Development 63 510-517.

Camargo LS, Viana JH, Sa WF, Ferreira AM \& Vale Filho VR 2005 Developmental competence of oocytes from prepubertal Bos indicus crossbred cattle. Animal Reproduction Science 85 53-59.

Coticchio G, Sereni E, Serrao L, Mazzone S, ladarola I \& Borini A 2004 What criteria for the definition of oocyte quality? Annals of the New York Academy of Sciences 1034 132-144.

Dennis G Jr, Sherman BT, Hosack DA, Yang J, Gao W, Lane HC \& Lempicki RA 2003 DAVID: database for annotation, visualization, and integrated discovery. Genome Biology 4 P3.

Dode MA, Dufort I, Massicotte L \& Sirard MA 2006 Quantitative expression of candidate genes for developmental competence in bovine two-cell embryos. Molecular Reproduction and Development 73 288-297.

Eppig JJ 1991 Intercommunication between mammalian oocytes and companion somatic cells. Bioessays 13 569-574.

Eppig JJ, Wigglesworth K \& Pendola FL 2002 The mammalian oocyte orchestrates the rate of ovarian follicular development. PNAS 99 2890-2894.

Fainsod A, Deissler K, Yelin R, Marom K, Epstein M, Pillemer G, Steinbeisser H \& Blum M 1997 The dorsalizing and neural inducing gene follistatin is an antagonist of BMP-4. Mechanisms of Development 63 39-50.

Fair T, Hyttel P, Motlik J, Boland M \& Lonergan P 2002 Maintenance of meiotic arrest in bovine oocytes in vitro using butyrolactone I: effects on oocyte ultrastructure and nucleolus function. Molecular Reproduction and Development 62 375-386.

Fair T, Gutierrez-Adan A, Murphy M, Rizos D, Martin F, Boland MP \& Lonergan P 2004a Search for the bovine homolog of the murine ped gene and characterization of its messenger RNA expression during bovine preimplantation development. Biology of Reproduction $\mathbf{7 0}$ 488-494.

Fair T, Murphy M, Rizos D, Moss C, Martin F, Boland MP \& Lonergan P $2004 b$ Analysis of differential maternal mRNA expression in developmentally competent and incompetent bovine two-cell embryos. Molecular Reproduction and Development 67 136-144.

Gandolfi F, Milanesi E, Pocar P, Luciano AM, Brevini TA, Acocella F, Lauria A \& Armstrong DT 1998 Comparative analysis of calf and cow oocytes during in vitro maturation. Molecular Reproduction and Development 49 168-175.

Gosden RG 2002 Oogenesis as a foundation for embryogenesis. Molecular and Cellular Endocrinology 186 149-153.

Gutierrez-Adan A, Rizos D, Fair T, Moreira PN, Pintado B, de la Fuente J, Boland MP \& Lonergan P 2004 Effect of speed of development on mRNA expression pattern in early bovine embryos cultured in vivo or in vitro. Molecular Reproduction and Development 68 441-448.

Hamatani T, Falco G, Carter MG, Akutsu H, Stagg CA, Sharov AA, Dudekula DB, VanBuren V \& Ko MS 2004 Age-associated alteration of gene expression patterns in mouse oocytes. Human Molecular Genetics 13 2263-2278.

Hosack DA, Dennis G Jr, Sherman BT, Lane HC \& Lempicki RA 2003 Identifying biological themes within lists of genes with EASE. Genome Biology 4 R70.

lemura S, Yamamoto TS, Takagi C, Uchiyama $H$, Natsume T, Shimasaki S, Sugino H \& Ueno N 1998 Direct binding of follistatin to a complex of bone-morphogenetic protein and its receptor inhibits ventral and epidermal cell fates in early Xenopus embryo. PNAS 95 9337-9342.

Izadyar F, Zeinstra E, Colenbrander B, Vanderstichele HM \& Bevers MM 1996 In vitro maturation of bovine oocytes in the presence of bovine activin A does not affect the number of embryos. Animal Reproduction Science 45 37-45.

Izadyar F, Dijkstra G, Van Tol HT, Van den Eijnden-van Raaij AJ, Van den Hurk R, Colenbrander B \& Bevers MM 1998
Immunohistochemical localization and mRNA expression of activin, inhibin, follistatin, and activin receptor in bovine cumulus-oocyte complexes during in vitro maturation. Molecular Reproduction and Development 49 186-195.

Khatir H, Lonergan P \& Mermillod P 1998a Kinetics of nuclear maturation and protein profiles of oocytes from prepubertal and adult cattle during in vitro maturation. Theriogenology 50 917-929.

Khatir H, Lonergan P, Touze JL \& Mermillod P 1998b The characterization of bovine embryos obtained from prepubertal calf oocytes and their viability after non surgical embryo transfer. Theriogenology 50 1201-1210.

Knight PG \& Glister C 2001 Potential local regulatory functions of inhibins, activins and follistatin in the ovary. Reproduction 121 503-512.

Knight PG \& Glister C 2003 Local roles of TGF-beta superfamily members in the control of ovarian follicle development. Animal Reproduction Science 78 165-183.

Krisher RL 2004 The effect of oocyte quality on development. Journal of Animal Science 82 E14-E23.

Levesque JT \& Sirard MA 1994 Proteins in oocytes from calves and adult cows before maturation: relationship with their development capacity. Reproduction, Nutrition, Development 34 133-139.

Livak KJ \& Schmittgen TD 2001 Analysis of relative gene expression data using real-time quantitative PCR and the $2(-$ Delta Delta $C(T))$ Method. Methods 25 402-408.

Lonergan P, Rizos D, Ward F \& Boland MP 2001 Factors influencing oocyte and embryo quality in cattle. Reproduction, Nutrition, Development 41 427-437.

Lonergan P, Rizos D, Gutierrez-Adan A, Fair T \& Boland MP 2003a Oocyte and embryo quality: effect of origin, culture conditions and gene expression patterns. Reproduction in Domestic Animals $\mathbf{3 8}$ 259-267.

Lonergan P, Rizos D, Gutierrez-Adan A, Moreira PM, Pintado B, de la Fuente J \& Boland MP 2003b Temporal divergence in the pattern of messenger RNA expression in bovine embryos cultured from the zygote to blastocyst stage in vitro or in vivo. Biology of Reproduction 69 1424-1431.

Majerus V, Lequarre AS, Ferguson EM, Kaidi S, Massip A, Dessy F \& Donnay I 2000 Characterization of embryos derived from calf oocytes: kinetics of cleavage, cell allocation to inner cell mass, and trophectoderm and lipid metabolism. Molecular Reproduction and Development 57 346-352.

Matzuk MM 1995 Functional analysis of mammalian members of the transforming growth factor-B superfamily. Trends in Endocrinology and Metabolism 6 120-127.

Matzuk MM, Burns KH, Viveiros MM \& Eppig JJ 2002 Intercellular communication in the mammalian ovary: oocytes carry the conversation. Science 296 2178-2180.

McKenzie LJ, Pangas SA, Carson SA, Kovanci E, Cisneros P, Buster JE, Amato P \& Matzuk MM 2004 Human cumulus granulosa cell gene expression: a predictor of fertilization and embryo selection in women undergoing IVF. Human Reproduction 19 2869-2874.

McKiernan SH \& Bavister BD 1994 Timing of development is a critical parameter for predicting successful embryogenesis. Human Reproduction 9 2123-2129.

Memili E \& First NL 1998 Developmental changes in RNA polymerase II in bovine oocytes, early embryos, and effect of alpha-amanitin on embryo development. Molecular Reproduction and Development 51 381-389.

Memili E \& First NL 1999 Control of gene expression at the onset of bovine embryonic development. Biology of Reproduction 61 1198-1207.

Memili E \& First NL 2000 Zygotic and embryonic gene expression in cow: a review of timing and mechanisms of early gene expression as compared with other species. Zygote 8 87-96.

Palma GA, Tortonese DJ \& Sinowatz F 2001 Developmental capacity in vitro of prepubertal oocytes. Anatomia, Histologia, Embryologia 30 295-300. 
Pan H, O'Brien MJ, Wigglesworth K, Eppig JJ \& Schultz RM 2005 Transcript profiling during mouse oocyte development and the effect of gonadotropin priming and development in vitro. Developmental Biology 286 493-506.

Patel OV, Suchyta SP, Sipkovsky SS, Yao J, Ireland JJ, Coussens PM \& Smith GW 2005 Validation and application of a high fidelity mRNA linear amplification procedure for profiling gene expression. Veterinary Immunology and Immunopathology 105 331-342.

Phillips DJ 2005 Activins, inhibins and follistatins in the large domestic species. Domestic Animal Endocrinology 28 1-16.

Plante L, Plante C, Shepherd DL \& King WA 1994 Cleavage and 3Huridine incorporation in bovine embryos of high in vitro developmental potential. Molecular Reproduction and Development 39 375-383.

Revel F, Mermillod P, Peynot N, Renard JP \& Heyman Y 1995 Low developmental capacity of in vitro matured and fertilized oocytes from calves compared with that of cows. Journal of Reproduction and Fertility 103 115-120.

Rizos D, Ward F, Duffy P, Boland MP \& Lonergan P 2002 Consequences of bovine oocyte maturation, fertilization or early embryo development in vitro versus in vivo: implications for blastocyst yield and blastocyst quality. Molecular Reproduction and Development $61234-248$.

Sakkas D, Shoukir Y, Chardonnens D, Bianchi PG \& Campana A 1998 Early cleavage of human embryos to the two-cell stage after intracytoplasmic sperm injection as an indicator of embryo viability. Human Reproduction 13 182-187.

Salamone DF, Damiani P, Fissore RA, Robl JM \& Duby RT 2001 Biochemical and developmental evidence that ooplasmic maturation of prepubertal bovine oocytes is compromised. Biology of Reproduction 64 1761-1768.

Seidel GE, Larson LL Jr, Spilman CH, Hahn J \& Foote RH 1971 Culture and transfer of calf ova. Journal of Dairy Science 54 923-926.

Shoukir Y, Chardonnens D, Campana A, Bischof P \& Sakkas D 1998 The rate of development and time of transfer play different roles in influencing the viability of human blastocysts. Human Reproduction 13 676-681.

Silva CC \& Knight PG 1998 Modulatory actions of activin-A and follistatin on the developmental competence of in vitro-matured bovine oocytes. Biology of Reproduction 58 558-565.

Silva CC, Groome NP \& Knight PG 2003 Immunohistochemical localization of inhibin/activin alpha, betaA and betaB subunits and follistatin in bovine oocytes during in vitro maturation and fertilization. Reproduction 125 33-42.
Silva JR, van den Hurk R, van Tol HT, Roelen BA \& Figueiredo JR 2004 Gene expression and protein localisation for activin-A, follistatin and activin receptors in goat ovaries. Journal of Endocrinology $\mathbf{1 8 3}$ 405-415.

Steeves TE \& Gardner DK 1999 Metabolism of glucose, pyruvate, and glutamine during the maturation of oocytes derived from prepubertal and adult cows. Molecular Reproduction and Development 54 92-101.

Stock AE, Woodruff TK \& Smith LC 1997 Effects of inhibin A and activin A during in vitro maturation of bovine oocytes in hormone- and serum-free medium. Biology of Reproduction 56 1559-1564.

Suchyta SP, Sipkovsky S, Kruska R, Jeffers A, McNulty A, Coussens MJ, Tempelman RJ, Halgren RG, Saama PM, Bauman DE, et al. 2003 Development and testing of a high-density cDNA microarray resource for cattle. Physiological Genomics 15 158-164.

Telford NA, Watson AJ \& Schultz GA 1990 Transition from maternal to embryonic control in early mammalian development: a comparison of several species. Molecular Reproduction and Development 26 90-100.

Tusher VG, Tibshirani R \& Chu G 2001 Significance analysis of microarrays applied to the ionizing radiation response. PNAS $\mathbf{9 8}$ 5116-5121.

Van Tol HT, Loos FAM, Vanderstichele HM \& Bevers MM 1994 Bovine activin $A$ does not affect the in vitro maturation of bovine oocytes. Theriogenology 41 673-679.

Whelan JA, Russell NB \& Whelan MA 2003 A method for the absolute quantification of cDNA using real-time PCR. Journal of Immunological Methods 278 261-269.

Yoshioka K \& Kamomae H 1996 Recombinant human activin A stimulates development of bovine one-cell embryos matured and fertilized in vitro. Molecular Reproduction and Development 45 151-156.

Yoshioka K, Suzuki C \& Iwamura S 1998 Activin A and follistatin regulate developmental competence of in vitro-produced bovine embryos. Biology of Reproduction 59 1017-1022.

Zhang X, Jafari N, Barnes RB, Confino E, Milad M \& Kazer RR 2005 Studies of gene expression in human cumulus cells indicate pentraxin 3 as a possible marker for oocyte quality. Fertility and Sterility 83 1169-1179.

Received 28 January 2006

First decision 9 March 2006

Revised manuscript received 13 June 2006

Accepted 20 September 2006 